\title{
Teenswoordige geskiedenis: Michel Foucault in gesprek met die teologie ${ }^{1}$
}

\author{
Johann Beukes (Weltevredenpark) \\ Navorsingsassosiaat: Departement Nuwe-Testamentiese Wetenskap \\ Universiteit van Pretoria
}

\begin{abstract}
Present History: Michel Foucault in conversation with theology

Philosopher Michel Foucault's work has become a major strand of what is often referred to as "postmodern theology". The wider relevance of his work for theology nevertheless still remains unexamined. This contribution serves as a review article of the book Michel Foucault and theology: The politics of religious experience (2004), edited by James Bernauer and Jeremy Carrette. It deals with "present history" as a leitmotiv in Foucault's work, before presenting a summary of this collection of essays by a group of leading Foucault scholars on a variety of themes within the history, thought and practice of theology. The book is described as a fascinating contribution to Foucault scholarship, which demonstrates, for the first time, the influence and growing importance of Foucault's work for contemporary theology.
\end{abstract}

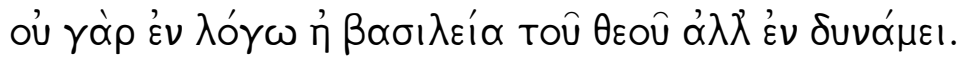

Die koninkryk van God is tog nie 'n saak van woorde nie, maar van mag

(1 Korintiërs 4:20).

\section{1. 'N TEOLOGIESE LESING VAN FOUCAULT?}

Talle dimensies in die Franse filosoof Michel Foucault (1926-1984) se werk, twintig jaar na sy dood, is nog betreklik onontgind. Dit geld veral vir sy estetika, die wyse waarop hy tematies met vroeë Frankfurtse eksponente soos Benjamin, Adorno en Horkheimer skakel en ook, nie onbelangrik nie, die wyse waarop Foucault se werk teologies geïnterpreteer kan word, veral met

\footnotetext{
${ }^{1}$ Oorsigartikel: Bernauer, J \& Carrette, J (eds) 2004. Michel Foucault and theology: The politics of religious experience. Hampshire: Ashgate. Hierdie artikel word opgedra aan prof Andries Breytenbach, ' $n$ gewaardeerde leermeester. Dr Johann Beukes (DLitt et Phil, PhD) is as navorsingsassosiaat betrokke by prof $\mathrm{dr}$ Andries $\mathrm{G}$ van Aarde se navorsingsprojek "Bybelse Teologie en Hermeneutiek", Departement Nuwe-Testamentiese Wetenskap, Fakulteit Teologie, Universiteit van Pretoria.
} 
verwysing na 'n teologiese epistemologie, die teologiese rehabilitering van die liggaam en die soort seksuele mandate wat Foucault tot die liggaam voeg, asook 'n Foucauldiaanse institusiegeskiedenis van die kerk (vgl Beukes 1996, 2002a). As sekerlik een van die mees gekommentarieerde filosowe vanuit Frankryk die afgelope vier dekades, sou 'n mens kon aanneem dat die literatuur in teologiese verband algaande sal groei, maar tans moet die literatuur nog as sporadies en wisselvallig beskryf word (vgl Bernauer 1999:xii e v).

Foucault se relevansie vir die teologie moet egter binne die breër konteks van die gesprek tussen teologie en filosofie in hulle eietydse gedaantes verstaan word. Dit kan as 'n gegewe aanvaar word dat die gesprek tussen kontinentale filosofie en teologie die afgelope jare verdiep het, met verwysing na die aanbod van 'n sogenaamde "postmoderne teologie". 2 Ongetwyfeld is dit die werk van Jacques Derrida, waarin teologiese temas by herhaling voorkom, wat die gesprek tussen kontinentale filosofie en eietydse teologie tot dusver grootliks gestempel het (vgl Rayment-Pickard 2003:17 e v; Ten Kate 1999:118 e v). Daar bestaan egter ook 'n groeiende waardering van die implikasies wat sommige van die ander sogenaamde "poststrukturalistiese" denkers (vgl Beukes 2002b:997 e v) in die Franse intellektuele tradisie vir die teologiese gesprek van die 21 e eeu inhou (vgl reeds Ray 1988:10 e v; meer onlangs Kelley 2002:89). Nuwe vertalings en resepsies van tekste van denkers soos Lyotard, Deleuze en Baudrillard vorm reeds 'n bykans selfstandige literatuur wat klassieke teologiese vrae weer wil vra (vgl Crockett 2001:37 e v; Poxon 2000:49; Baudrillard \& Gane 1993:3641).

Dit geld ook vir die oeuvre van Foucault en die sekondêre literatuur wat, soos genoem, stadig maar seker besig is om daaruit voort te kom. Onlangse vertalings, kommentare en studies in die Foucault-navorsing dui inderdaad op onverkende teologiese dimensies in Foucault se werk. In

\footnotetext{
${ }^{2}$ Die begrip "postmoderne teologie" is problematies, hoe hoog ook al die frekwensie en vrymoedigheid van gebruik in die eietydse literatuur (vgl bv Beardslee et al 1989:vii; Tilley 2000:27 \& Westphal 2001:17). Die problematiese aard vestig in die misleidende, selfs ambivalente kwaliteit daarvan. Enersyds kan die begrip 'n periodisering van die teologie veronderstel, verwysende na teologie "na moderniteit". Indien dit die geval is, verraai dit juis 'n modernistiese opvatting van die geskiedenis en is dit juis nie sogenaamd "postmodern" nie. Eerder sou begrippe soos redekritiese teologie of modernkritiese teologie in so 'n periodisering of epogstelling van die teologie deug. Andersyds kan die begrip "postmoderne teologie" 'n filosofiese (selfs filosofies-polemiese) stellingname in oog hê, waarmee 'n tematiese solidariteit met die post-strukturalistiese wending in die Franse filosofie in die besonder aangedui word. Indien dit die geval is, deug die begrip in elk geval nie, vanweë die intrinsieke spanninge wat opgesluit is in hierdie wending self (vgl Beukes 2002b:997-1001): Kortom: "Postmoderne teologie" is ' $n$ té gelade, onhandige en polemiese begrip om as teologiese merker of werksbegrip ingespan te word. Meer beskeie begrippe soos modernkritiese teologie of selfs "estetiese teologie" (vgl Viladesau 1999:12) sou eerder binne hierdie kritiese konteks kon deug.
} 
Foucault se werk is daar byvoorbeeld 'n soort godsdienssin aanwesig wat nou versoenbaar is met die konfessionele agenda en die visuele vroomheidsbegrip in die Rooms-Katolieke tradisie (vgl Dillon 1999:18). In dieselfde asem egter, is daar in Foucault se werk - tendensieus - kritiese analises van moderne institusies aanwesig, wat juis weer in gesprek met die hiperinstitusionele karakter van die Rooms-Katolieke tradisie, maar ook die institusionele karakter van die "heilige algemene Christelike kerk" self, sou wou tree (vgl Carrette 1999:1-6; Caputo \& Yont 1993:24). Hierdie institusiekritiek open 'n ondersoek na die wyer maatskaplike en politieke agenda van teologie. Met ander woorde, Foucault tree terselfdertyd met die Christelike tradisie én die dissiplinêre regimes daarvan in gesprek. Hy is spanningsvol die bewaker én uitdager van die Christelike tradisie. Hy verteenwoordig 'n belofteryke spanning waarin die moontlikheid van nuwe verhoudings binne die Christelike tradisie wat meer inklusief en minder afgrensend en selfs onderdrukkend is, tot uitdrukking gebring kan word.

In 2004 verskyn daar 'n besondere versameling Foucault-studies wat hierdie inderdaad teologiese spanning sistematies ondersoek, te wete redakteurs James Bernauer en Jeremy Carrette se Michel Foucault and theology: The politics of religious experience. Afgesien daarvan dat hoogs gerespekteerde medewerkers soos John Caputo, Thomas Flynn en Andrew Cutrofello insiggewende bydraes in die bundel lewer, is dit die eerste maal dat implikasies van Foucault se werk sistematies ten opsigte van temas soos die patristiek, die politiek van teologie, teologiese epistemologie en 'n liggaamsteologie binne eenheidsverband ondersoek en as 'n korpus byeengebring word. Dit is 'n besonder uitdagende en veeleisende versamelwerk wat in die Foucault-navorsing sonder twyfel respek sal afdwing en daarbinne 'n gerekende plek sal beklee.

Twee temas lê stilswyend ten grondslag van die poging om oor Foucault se gesprek met die teologie, en daarom ook oorsigtelik oor die bydraes in hierdie versamelwerk, te probeer praat, te wete 1) die soort voorwaarde wat Foucault aan teologiese kennis sou wou stel en 2) Foucault se bemoeienis met teologiese "stiltes". Die retoriese ruimte wat hierdie twee geleiers skep, sou ons daartoe kon bring om, saam met die medewerkers in hierdie versamelwerk, Michel Foucault se gesprek met die teologie voorlopig te omlyn.

\section{TEENSWOORDIGE GESKIEDENIS:}

'N FOUCAULDIAANSE LEITMOTIV VIR GESPREK MET DIE TEOLOGIE

Hoe is teologie moontlik? Wat is die voorwaardes vir teologiese kennis en wat bemoontlik die teologiese diskoers op enige gegewe stadium van die 
geskiedenis? Hierdie soort vrae neem Foucault se argeologiese en genealogiese projekte ${ }^{3}$ na die sentrum van die teologie, in die sin dat dit die moontlikheid van teologie as 'n kennisvorm wat binne die historiese proses gevorm word, wil oorweeg. Die teologiese diskoers tree binne bepaalde historiese tydsgewrigte na vore, na gelang van die kennisstrukture - of epistemiese strukture, om Foucault skerper na te praat - wat teologiese postulate op daardie stadium moontlik gemaak het (oftewel die argeologie van teologiese kennis). Die teologiese diskoers tree ook na vore in die verhouding tussen subjekte en institusies en die wyse waarop hierdie verhouding tussen subjek en institusie die diskoers self bepaal (oftewel die genealogie van teologiese kennis). Dit beteken dat begrippe soos eksegese, openbaring, selfbegrip en Godsbegrip gevorm word deur die dominante kennisvorme - of regimes van kennis - wat beskikbaar was op 'n bepaalde stadium van die geskiedenis (vgl Rogerson 2000:37).

Hierdie historisering van teologiese kennis, gegewe die stemming in die eietydse filosofie, val vandag bykans vanselfsprekend op: Die saak waaroor dit egter ten diepste gaan, is dat hierdie historisering telkens ' $n$ spanning in die verhouding tussen kultuur en teologie skep. Die spanningsvolle korrelasie van teologie met ' $n$ eietydse kultuur is inderdaad van deurslaggewende belang in die vorming van die Christelike tradisie: Dit word tans ook weer ervaar in die sogenaamde postmoderne debat in die teologie, waar die Christelike tradisie ten aansien van 'n veranderende kultuurbegrip en drastiese kenniswendinge skerp tot verantwoording geroep word (vgl Beukes 2000:215). Dit sou hiervolgens moontlik en selfs nodig wees om tipes teologieë te identifiseer en van mekaar te differensieer op grond van teoloë se ontvanklikheid vir impulse vanuit die kultuurkritiese debatvoering van hulle tyd (vgl Frei 1992). Die veelvoud van spanningsvolle relasies tussen teologie en 'n eietydse kultuur is dan ook, om die klassieke standpunt van Niebuhr (1951) na te praat, die blywende probleem van die teologie. Die blywende aard van hierdie probleem word ook vandag, binne die ruimtes van 'n modernkritiese teologie bevestig, sowel in die filosofiese kritiek van moderniteit as die toenemende prolifiering van die gevestigde en opgestelde grense tussen kultuur en teologie.

Michel Foucault speel op hierdie blywende probleem in die eietydse gedaante daarvan in, wanneer hy sistematies vrae oor die aard en aansprake van tradisie, ruimte, outoriteit en mag in die teologie stel. Sy werk moet daarom teen die agtergrond van die steeds-ontwikkelende geskiedenis van

\footnotetext{
${ }^{3}$ Foucault se kennisleer vertrek vanuit die konsepte "argeologie" en "genealogie". Argeologie wil poog om die waarheidstigtende elemente in 'n diskoers te identifiseer, waarom dit as "kennis" (dus as "waar", "redelik" of "mooi" of "goed") sou geld. Genealogie (kyk Foucault 1977:145-146) wil verder gaan en die oorspronge van hierdie diskoerse identifiseer, hoé diskoerse dus gevorm word, maar veral, waarom diskoerse histories varieer.
} 
die Westerse Christendom verstaan word, veral ten opsigte van sy analise van die kulturele waardes van moderne institusies: Dit is ' $n$ analise wat die teologie terug in die geskiedenis bring, 'n analise wat die grondslae van teologiese kennis - gegewe dus die stand van kultuur en kennis vandag herondersoek.

Foucault se "filosofiese historiografie", soos wat ek verkies om na sy projek te verwys (in die sin dat dit nóg filosofie nóg geskiedskrywing in die gangbare, moderne sin van die woord is), verseg om teologie en kultuur van mekaar te skei. Teologie word nie by Foucault geïsoleer in 'n binêre konstruksie waar die veronderstelde lyn waar teologie eindig en eietydse kultuur begin, duidelik sigbaar en identifiseerbaar is nie. Teologie het 'n geskiedenis en juis daardie geskiedenis reflekteer die voortgaande gebedheid van teologie in kulturele omgewings. Teologie ontwikkel deur middel van reekse ontmoetings, hoe weerbarstig soms ook al, met 'n eietydse wêreld. Teologie word aangespreek deur die politieke, filosofiese en sosiale waardes van die tyd, selfs daar waar teologie sigself sou verset teen daardie waardes, selfs daar waar teologie huiwerig is om die bestaan van daardie waardes te erken. So was dit met die teologie se oorweging van die neo-Platoniese filosofie, met die nuwe affirmering van die teologie by Aquinas, ten opsigte van die talle ekskurse van Marx, Nietzsche, eksistensialisme en neoMarxisme: Teologie wou die waarheid van die teologie praat, gegewe die waardes, voorwaardes en belange van die tyd.

Tog sou 'n mens kon beweer dat "geskiedenis" in die teologie normaalweg steeds 'n "verbeelde ruimte" behels waarin die politiekteenswoordige bestendig word, 'n verbeelde ruimte waarin die verlede as 't ware kwytgeskeld word van die plig om die waarheid van die teenswoordige te wees. Dit sou ook anders gesê kon word: Die stryd van die teologie is om tradisie as verandering eerder as 'n versugting na behoud te beskou, 'n versugting wat die huidige politiek van teologie telkens verberg deur die aksent op 'n konstant verbeelde en telkens herverbeelde verlede te plaas. ${ }^{4}$

\footnotetext{
${ }^{4}$ Dit geld veral vir die teologie se gevestigde hunkering na beginsels van identiteit. Hierdie beginsels van identiteit voorsien teologie van ' $n$ verbeelde kontinuïteit en verbeelde sekerheid. Enersyds voorsien tipiese beginsels van teologiese identiteit, soos die belydenisskrifte, kerklike statute en die gangbare (of dan, kerklike) interpretasie van die kerkgeskiedenis, kriteria waarmee daar met die moontlikheid van 'n aanspraak op 'n eksterne of "objektiewe" gegewe, selektief aspekte van die sosiale werklikheid verreken en ongehinderd na ander historiese kontekste verplaas kan word. Andersyds voorsien hierdie beginsels van identiteit gemene sosiale delers of sosiale noemers waarvolgens met stelligheid vasgestel sou kon word of eietydse idees, handelinge en so meer (nog) deel vorm van die bestaande teologiese kennissisteem, die tradisie, die kerklike gebruik, en so meer. Dit word dan betreklik maklik om ongewensde of gevaarlike idees met 'n beroep op die geskiedenis uit te weer en sodoende die huidige politiek van teologie te kamoefleer. Dit is juis in hierdie vermoë tot maskering van teenswoordige belange, dat die stilte van teologie merkbaar/hoorbaar word.
} 


\section{Michel Foucault in gesprek met die teologie}

Die teologie in gesprek met Michel Foucault herken en eerbiedig juis die teenswoordige geskiedenis. Wanneer teologie in eietydse gedaante hierdie teenwoordige geskiedenis herken, erken dit ineens ook die feit dat enige beroep op die verlede, paradoksaal, 'n bevestiging is van die huidige politieke begeerte na kennis en mag aangaande die aard van "waarheid". Indien teologie die argaïese preservering van hierdie telkens (her)verbeelde verlede te bowe sou wou kom, sou teologie dus bereid moet wees om telkens die inhoud en aansprake van sy eie tradisie in die nuwe ruimtes van 'n eietydse wêreld sonder vrees of vooroordeel te onderhandel.

Hoe sou die hermeneutiek van só 'n teologie lyk? Dalk sou 'n mens kon sê dat die taak van so 'n hermeneutiek gerig sou kon wees op die ontmaskering van die ideologiese distorsie in (of die sosio-historiese geladenheid van) 'n bepaalde tradisie. By Foucault leer ons dat dít wat ons probeer verstaan, voortdurend en sistematies besig is om die bindinge daarvan met mag en onderwerping te konfigureer as iets anders, oftewel dat ons in die verstaansproses mislei word deur die konfigurering of maskering van mag. Foucault toon aan dat alle kennisvorme sosio-historiese- en tradisiegebonde gegewes is wat die werklikheid nie kan begryp "soos wat dit is" nie. Kennisvorme is na Foucault se mening besig om vanuit 'n bepaalde sosio-historiese raamwerk of "tradisie" deel te neem aan die werklikheid en is self besig om te skep of te interpreteer, eerder as wat kennisvorme as ontdekkend of dokumenterend van aard beskou kan word.

Foucault beskou juis daarom denkkategorieë wat verwyderd is van die praktyke van 'n eietydse, lewende, deelnemende gemeenskap as die groot "illusie van die teologie" (vgl Foucault 1997:30). Teologie, sou 'n mens anders kon sê, is dus voortdurend in 'n stryd gewikkel tussen die waardes van tradisiebewaring en tradisie-interpretasie. Indien teologie dit sou wou vermy om bloot ' $n$ ensiklopedie van die verlede of 'n elitistiese model van ortodoksie te wees, sou teologie bereid moes wees om telkens die teenswoordige geskiedenis as voorwaarde vir teologiese kennis en die ontmaskering van die politiek van teologiese denke te verken. Foucault se werk verskaf juis die geleentheid om hierdie teenswoordig-historiese voorwaardes vir teologiese kennis te ondersoek. In hierdie ondersoek sou dit moontlik word om die ideologiese distorsies in die teologie self te identifiseer, of, om Foucault skerper na praat, die verskuilde regimes van mag onderliggend aan die baie deugde van die teologie, uit te wys. Teologies sou 'n mens kon sê: Foucault haal teologie uit die dogmatiese korset en dwing dit terug na die pastorale werklikheid toe. Foucault ontwapen die dogmatiek deur die donker onderbewuste van teologiese kennis uit te wys.

Teologie loop volgens Foucault die risiko om die eie bewussynsvelde te vernou wanneer gesag en outoriteit deur blinde rasionaliteit toegeëien word, in stede van die bewustelike en kritiese herkenning van hierdie donker 
onderbewuste, wat per definisie aanwesig is in elke teologiese gedagte en uitspraak. Teologie kies volgens Foucault bykans instinktief vir die bevestiging van outoriteit, eerder as wat die eie verwondbaarhede en die verwonding van subjekte in die lewende, deelnemende gemeenskap ondersoek word. Foucault wil hierdie verwondbaarheid én verwonding teenswoordig-histories ondersoek. ${ }^{5}$ Daarin vestig die waarde van Foucault se gesprek met die teologie.

\section{3. 'N OOPSKRYF VAN TEOLOGIESE STILTES}

Op fassinerende wyse verken die medewerkers in Bernauer \& Carrette (2004) die stille teenwoordigheid van verwonding in die teologie, deur by die kritiese Leitmotiv van Foucault se teenswoordige geskiedenis aansluiting te vind. Die versamelwerk bestaan uit vier afdelings, wat Foucault se gesprek met die teologie oor uiteenlopende temas heen, bestryk.

Deel I fokus op die implikasies van Foucault se gedagtes vir 'n herlesing van klassieke, Bybelse en patristiese tekste. Hierdie afdeling moet geplaas word binne die ongepubliseerde ruimte van Foucault se vierde studie oor die Christendom, 'n studie wat deur Foucault-navorsers steeds as enigmaties beskou word (vgl Carrette 1999:1-6 oor die poging om die ongepubliseerde fragmente byeen te bring). Elizabeth Castelli tree as inleier in hierdie afdeling op met haar klassieke ${ }^{6}$ studie oor Korintiërs 1 , "Interpretation of Power in 1 Corinthians" (Bernauer \& Carrette 2004:19-38). In haar teks ondersoek Castelli Paulus se diskoers, sy verhouding met sy gespreksgenote (die gelowiges in Korinte) en toon sy die wyse aan waarop diskoers en mag in Paulus se denke, juis ten aansien van die gemeente van die Korintiërs as "Ander", figureer. Deur in te speel op wat sy "woordelikse toevallighede" tussen Paulus en Foucault noem, om vandaar 'n "eietydse kultuurkritiese" lesing van 1 Korintiërs te konstrueer, identifiseer Castelli se uiters opwindende teks prominente magstrategieë in die eerste Korintiërsbrief.

\footnotetext{
${ }^{5}$ Foucault sensiteer die teologie vir die magshandeling van uitsluiting en onderdrukking wat diep weggebêre lê in die teologiese diskoers, sisteem, handelingskonteks en institusie: Die slagoffers van hierdie uitsluiting is die so genoemde Ander (vgl Beukes 1996:234-235). Foucault stem die teologie veral bedag op die tipies-moderne konfigurasie van mag: Onderwerping na binne en na buite word gekonfigureer as wesenlik aanvaarbaar, wenslik, legitiem en selfs noodwendig. "Teologie" konstitueer volgens Foucault ' $n$ magvolle verskynsel wat skuilgaan onder die pretensie dat dit besig is met die "hoëre goeie", die transendente, terwyl dit wesenlik ' $n$ immanente verskynsel is wat die mag tot beskikking voortdurend in selfbelang herkonfigureer as onbetwyfelbare proposisies (vgl Beukes 1996:236 e v; 2000:215 e v).

${ }^{6}$ Castelli se teks "Interpretation of Power in 1 Corinthians" is reeds in 1992 in Semeia 54 (199-222) gepubliseer. Haar teks was in die Foucault-navorsing die eerste om Foucault se analise van die verhouding tussen diskoers en mag na die navorsingsvelde van die NuweTestamentiese Wetenskap te neem. Sonder uitsondering word haar werk ook gesiteer in teologiese analises van Foucault na 1992. In hierdie opsig kan Castelli se teks as klassiek, dalk selfs as epogmakend, beskou word.
} 


\section{Michel Foucault in gesprek met die teologie}

Castelli slaag naamlik daarin om die funksies van mag in die eerste Korintiërsbrief uit te wys, deur die meervoudigheid van diskoerse wat in die teks aanwesig is, in die sentrale gedeelte van haar teks af te speel teen wat sy beskou as Paulus se posisie as "bevoorregte spreker" (Castelli 2004:33). Paulus se "eenheidsdiskoers" vis-à-vis die Korintiërs se "meervoudighede en diffusie" word effektief deur Castelli ingespan om temas soos marginalisering en onderdrukking wat op sterkte van haar Foucauldiaanse lesing van die teks prominent in die teks teenwoordig is, uit te wys en daarop voort te borduur (Castelli 2004:33 e v). Castelli se bydrae vestig die aandag ondubbelsinnig op die kreatiewe en kritiese waarde van Foucault se Leitmotiv vir die Bybelse hermeneutiek en dien as bevestiging dat 'n Bybelse hermeneutiek wat onafhanklik van eietydse kritiese teorieë probeer funksioneer, ernstig probleme post-Foucault sal ervaar.

Die tweede bydrae in Deel I van die versamelwerk is 'n Foucauldiaanse gesprek met die patristiek, te wete Elizabeth Clark se "Foucault, the fathers and sex". Ook hierdie teks is reeds vyftien jaar gelede gepubliseer en in herverwerkte vorm in Bernauer \& Carrette (2004) opgeneem. Reeds in 1988 het hierdie opstel diep spore ${ }^{7}$ in die Foucault-navorsing getrap, sowel ten opsigte van die resepsie van Foucault se trilogiese History of sexuality as die korrektheid van Foucault se eie lesings van klassieke tekste en die implikasies daarvan vir studies in die patristiek. Nadat Clark haar eie resepsie van History of sexuality omlyn (en Foucault se argument kursories maar toeganklik ook aan 'n oningewyde leserspubliek bekendstel [Clark 2004:4244]), bring sy, as by uitstek navorser in die patristiek, enkele kritiese korrektiewe op Foucault se lesing van Grieks-Romeinse en vroeg-Christelike benaderings tot die liggaam as erotiese ruimte aan (Clark 2004:45-50). 'n Belangrike fokusverskuiwing wat Clark aanbring, is die sentralisering van die vroeë monnike se daadwerklike angs ten opsigte van seksualiteit, wat 'n wending op Foucault se konklusie dat die kloosterbestaan bloot 'n stille terugtrekking van seksualiteit (as sex in the head) verteenwoordig.

Clark se teks spreek van deeglikheid, bedrewenheid en die vermoë om Foucault se historiese analises krities in heroënskou te neem. Wie ook al Foucault se seksualiteitsanalise bestudeer het, sal Clark se bekwame analise van Foucault se trilogie as 'n opwindende en stimulerende addendum, selfs 'n erratum, hoe onbeskeie dit ook al mag aandoen in die intimiderende aansig van sy groter oeuvre, tot die Foucault-teks vind.

Die laaste bydrae in die eerste gedeelte van die versamelwerk skep eweneens 'n nuwe navorsingsregister ten opsigte van Foucault, die patristiek

\footnotetext{
${ }^{7}$ Clark se teks is aanvanklik in die Journal of the American Academy of Religion 56(4), 619641, (Oxford University Press 1988) gepubliseer en het bykans onmiddellik 'n gesprek tussen Foucault en kerkhistorici van die grond af gekry (vgl Dillon 1999:67 e v).
} 
en die laat-klassieke tyd. Joyce Schuld se "Augustine, Foucault and the politics of imperfection" volstaan egter nie met 'n ondersoek na betekenisvolle ladings in die Foucault-argief ten opsigte van die patristiek nie, maar ondersoek juis die wyse waarop Foucault se werk 'n gesprek tussen die premoderne en die postmoderne fasiliteer. Schuld toon aan dat daar tussen Foucault en Augustinus, met inbegrip van 'n verskil van 15 eeue, enorme kulturele afstande en radikaal uiteenlopende werklikheidsbegrippe, intieme tematiese parallele bestaan. Schuld vind veral noue ooreenkomste tussen Augustinus en Foucault se politieke voorbehoude oor die funksionering van institusionele mag en die "morele" onvoltooidheid van elke menslike handeling, onderneming en struktuur. Schuld (2004:59) toon oortuigend aan dat Foucault nie as 'n bedreiging of kompromiteerder ${ }^{8}$ van die waardeoordelende fakulteite van die Christelike tradisie beskou moet word nie, maar eerder as 'n bron van kritiese nadenke oor die tradisie, juis as teenswoordige geskiedenis, juis met sy onkonvensionele ondersoeke, juis in die sowel "profetiese as ontstellende" element van sy werk (Schuld 2004:70-71). Schuld (2004:63-66) fokus op tematiese parallele tussen Augustinus se City of God en Foucault se Discipline and punish in die besonder. Beide tekste, na Schuld se lesing, staan agterdogtig teenoor enige retoriek wat spreek van "kulturele bevoorregting" of "diskoerspriviligering" ('n bevinding wat resoneer met Castelli se Korintiërlesing supra). Augustinus se skerp-bewoorde voorbehoude oor die aansprake van "imperiale glorie" en Foucault se ewe skerp-bewoorde kritiek van die Verligtingsmatige belydenis van "wetenskaplike vooruitgang", het volgens Schuld dieselfde oorsprong, naamlik die kritiek en bevraagtekening van self-evidente outoriteit, of, strukture van outoriteit wat as self-evident geag word. Schuld dui met omvangryke tekstuele analises en fyn tekstuele jukstaposisies aan dat beide Augustinus en Foucault hulle lesers om dieselfde oorweging bewustelik skok, naamlik om die morele orde van hulle dag af te takel, 'n nuwe (politieke) gewydheid aan die wêreld te bevorder en die menslike kondisie, juis in die lig van die breekbaarheid en, om die berugte Foucault-woord te gebruik, "vuilheid" daarvan, te bly omarm. In kort: Beide Augustinus en Foucault bevorder 'n anti-triomfantelike antropologie en 'n anti-utopiese benadering tot hulle onderskeie wêrelde.

Die tweede deel in Bernauer \& Carrette beslaan meerendeels godsdiensfilosofiese evaluasies van Foucault se analise van teologiese

\footnotetext{
${ }^{8}$ Schuld ondersoek op 'n breër front ook die probleme wat intrinsiek en spanningsvol opgesluit is in Foucault se gesprek met die teologie en klaar heelwat misverstande in die verband op.
} 
politiek. ${ }^{9}$ Ook hier vind ons, soos in Deel I, uiters opwindende bydraes wat spreek van besondere erudisie in die Foucault-navorsing. James Bernauer self open Deel II (Foucault, politics and theology) met 'n besonder waardevolle lesing van Foucault se nagelate fragmente oor die religie en sy lesings by die Collège de France in 1975 oor die geskiedenis van die Christendom $^{10}$ (Bernauer 2004:78): "Michel Foucault's Philosophy of Religion: An introduction to the non-Fascist life". Bernauer kenmerk Foucault se nadenke oor die religie as ' $n$ vorm van intellektuele verset teen die fascistiese verheerliking en produsering van 'n "gehoorsame subjek", wat na Foucault se analise in die geskiedenis van die Christendom as ideaal vir 'n betekenisvolle lewensvoering gestel is. Foucault se beskouing van die religie voltrek volgens Bernauer (2004:79 e v) op drie vlakke: In die eerste plek noodsaak Foucault se Leitmotiv van teenswoordige geskiedenis 'n blootlegging van die kontinuerende rol wat Christelike tradisies, problematiserings en "tegnologieë" speel in die definiëring en (paradoksale) bestendiging van moderniteit. Om dit eenvoudiger te stel: Christelike tradisies soos die Rooms-Katolieke biegpraktyk en die universiteitsbedding van die Protestantisme het moderniteit gehelp inisieer, indien hierdie tradisies nie selfs aangewys moet word as die belangrikste enkele, aanduibare faktore wat histories gelei het tot die opkoms van die Verligting en die groter projek van moderniteit nie. Ten tweede verskaf Foucault se denke, veral gedurende die latere fases van sy werk (met die publikasie van History of sexuality in die laat sewentigs tot en met Foucault se dood in 1984), die middele vir effektiewe selfkritiek in die teologie. $\mathrm{Na}$

\footnotetext{
${ }^{9}$ Die begrip "politiek" verwys in Foucault se werk na die wyse waarop mag in strukture opereer en in besonder die wyse waarop mag sigself binne strukture herkonfigureer as iets wat nie herkenbaar is as magsuitoefening nie. "Teologiese politiek" sou by Foucault dus verwys na die wyse waarop mag in die teologie opereer en veral die wyses waarop die teologie hierdie mag deur herkonfigurerende strategieë kamoefleer. Ten opsigte van Foucault se (veelbesproke en kontroversiële) beskouing van die wyse waarop mag funksioneer, ook net die volgende: Foucault se kritiese strategie behels wat Deleuze (1984:149) 'n "kontrafilosofie" noem. Hierdie kontra-filosofie behels dat Foucault heterogeniteit of partikulariteit nie soos die moderne filosofie in terme van die struktuur en sisteem van subjeksentrisme benader nie, maar vanuit die histories-varieerbare aard van mag. Mag is vir Foucault nie iets wat deur subjekte besit en onderwerp kan word en instrumenteel-diensbaar gestel kan word (soos rasionaliteit) nie. Mag is eerder ' $n$ alles-deurdringende netwerk van historiese verhoudings waaraan geen subjek kan ontkom nie. Subjekte is dus beide die agente en produkte van mag. Die verskynings van magsnetwerke wat dikwels, byvoorbeeld in politieke stelsels, as iets negatiefs beskou word, is volgens Foucault misplaas. Mag is nie iets wat "bo" is en wat uitgeoefen word op diegene wat "onder" is nie. Mag is oral. Mag sirkuleer deur elke sel van die sosiale liggaam, dit is die mees grondliggende aspek van elke institusie, handeling en verhouding. Foucault is dus nie afwysend oor mag nie. Foucault het dit eerder teen die moderne programme (of [historiese] "tegnologieë", soos hy dit noem) van dissiplinering en onderwerping, wat uit en uit met mag as medium werk, maar nie herkenbaar nie.

${ }^{10}$ Bernauer lewer met hierdie artikel 'n enorme bydrae tot die Foucault-navorsing deur Foucault se ongepubliseerde lesings en fragmente oor die religie te sistematiseer en vir die eerste maal in die navorsing (kyk ook die aanvoorwerk in Bernauer [1999]) as 'n hanteerbare korpus in die groter oeuvre aan te bied.
} 
Foucault se mening staan selfrefleksiwiteit intrinsiek en sentraal tot die Christelike oorlewering, maar dit het in die neuroses en newels van die Inkwisisie se brandstapels verdwyn. Hierdie selfrefleksiwiteit moet volgens Foucault gerehabiliteer word, indien enigsins vordering gemaak sou wou word met 'n teenswoordige geskiedenis van die Christendom. Ten derde beskou Bernauer Foucault se onvoltooide werk oor vriendskap (die tema van 'n reeks lesings by die Collège de France in 1984, waaraan Foucault tot op sy sterfbed nog gewerk het) as van deurslaggewende belang in 'n rekonstruksie van Foucault se godsdiensfilosofie. Foucault beskou vriendskap as 'n fundamentele teenvoeter vir die fascistiese projek van selfhaat en die skep van toestande van blywende vyandskap teenoor die Self en nyd teenoor die Ander.

Bernauer se artikel, in die soms spekulatiewe en noodwendig rekonstruktiewe aard daarvan, dui op die noodsaaklikheid van 'n spoedige byeenbring en publikasie van Foucault se gedagtes oor die religie, sodat dit deel kan uitmaak van die gesprek oor Foucault se nalatenskap in die publieke arena. Bernauer het reeds aanvoorwerk van onskatbare waarde met hierdie artikel gedoen, maar dit is noodsaaklik dat Foucault se godsdiensfilosofie as korpus gepubliseer sal word en as deel van die skopus van primêre tekste in die navorsing sal figureer. Nie net die Foucault-navorsing nie, maar die teologie self sal oneindig daarby baat.

Die tweede bydrae in Deel II fokus op Foucault se analise van 'n eietydse politieke gebeurtenis, naamlik die Iran Revolusie van 1978-1979. Bitter min navorsing is tot dusver gedoen oor Foucault se eie analise van hierdie historiese gebeurtenis en geen werk is nog gedoen oor die wyse waarop die gebeurtenis lig werp op Foucault se beskouing van die religie en die verhouding tussen mag en spiritualiteit nie. Michiel Leezenberg, 'n Amsterdamse navorser in die filosofie van Islam, toon werklik aktueel aan in welke mate Foucault die spirituele dinamika van Islam aangevoel en gebeure soos die slagting van 11 September 2001 in New York vooruitgeskat het. Leezenberg se artikel, "Power and political spirituality: Michel Foucault on the Islamic Revolution in Iran", plaas Foucault se "ideëjoernalistiek" oor die revolusie in perspektief en omlyn ineens ook implikasies van Foucault se denke vir 'n begrip van die magshandelinge van Islamitiese faksies in 'n eietydse Westerse wêreld. Leezenberg (2004:101-104) toon aan dat Foucault se analise van die revolusie, naamlik dat die gebeure in Iran 'n radikaal nuwe probleem ten opsigte van die begrippe mag, politiek, religie en spiritualiteit geformuleer het, volkome korrek was. Foucault was naamlik sensitief vir die nuwe stemme van verandering in Iran op 'n stadium toe Westerse intellektuele bykans sonder uitsondering hierdie beweging in Islam as 
regressief en as 'n terugval na die pre-moderne bestempel het. Foucault was besonder geïnteresseerd in die spiritualiteit van die massas wat teen die orde in opstand gekom het. Foucault sou die gebeure dan ook ontleed as as 'n soort politiek wat in verset gekom het teen gevestigde moderne politieke analises sowel as ' $n$ verset teen moderne regimes van onderdrukking, kontrole en beheer. In 'n tyd waar dit dringend noodsaaklik geword het om die komplekse wêrelde van Islam te karteer, het Foucault reeds, deur te fokus op die politiek van die betrokke religie, parameters aangelê om hierdie kartering met inagname van die idiosinkrasieë van mag, spiritualiteit en gehoorsaamheid in Islam, te kan begin. Deur tipies-Westerse vooroordele ten opsigte van rasionaliteit en die kontrole van die individu opsy te skuif, kon Foucault intelligente en deurdringende vrae ten opsigte van die revolusie stel, vrae wat uiteindelik vir 'n meer omvattende evaluasie en kritiek van religie as sodanig relevant blyk te wees.

Persoonlik staan ek ietwat bevooroordeeld ten opsigte van John Caputo se uitstaande artikel, "On not knowing who we are: Madness, hermeneutics and the Night of Truth in Foucault" (Caputo 2004). Aanvanklik gepubliseer in Caputo \& Yont (1993:233-262) met dieselfde titel en sonder noemenswaardige wysiging heropgeneem in Bernauer \& Carrette (2004:117130), het ek die artikel reeds enkele jare gelede gelees en het reeds toe onder die indruk gekom van Caputo, by uitstek Derrida-navorser, se vermoë om intellektuele konstellasies in die eietydse Franse filosofie met mekaar in gesprek te bring en ook om uiteenlopende temas vanuit 'n bepaalde denker se werk met mekaar te koppel en te integreer. Hierdie analise van Foucault se hermeneutiek en die koppeling daarvan met die religie is na my beskeie mening die belangrikste en gevolgrykste van al die (sonder uitsondering) uitstekende bydraes in Bernauer \& Carrette, omdat Foucault se hermeneutiek hier self bykans religieuse status verkry. Foucault se hermeneutiek leer ons: Ons is nooit seker wie ons is nie (Caputo 2004:119-120). Ons staan in onkunde voor onsself oor onsself. Hierdie onwete noem Foucault die "nag van waarheid". Hierdie gebrek aan ' $n$ finale affirmering van die Self verteenwoordig vir Foucault die aantreklike aan die religie: 'n "Wyse onkunde van die Self", 'n afwysing van daardie positiewe, kenbare entiteite wat vir mense gefabriseer word ten einde daardie entiteite te bemeester: Dit begin by die Self en, sou 'n mens sekerlik kon sê, eindig by God.

Caputo stel met ' $n$ meesterlike analise van Foucault se Madness and civilization Foucault se hermeneutiek voor as 'n hermeneutiek van verset teen hele reekse humanistiese kennisbronne, hulle "resultate" en hulle "konklusies": homo psychologicus, homo economicus, homo religiosus. Alle waarheid aangaande die mens word volgens Foucault deur die mens self 
platgeloop (Caputo 2004: 123-126). Deur as mens getuie te wees van hierdie onoplosbare negatiwiteit van menswees, in die begrip dat ons nie kan wees wat ons (letterlik) voor-geskryf word om te wees nie, tree 'n nuwe vryheid na vore, 'n vryheid wat differensie verwelkom. Hierdie differensie open volgens Caputo besondere uitreikmoontlikhede na ander, bemoontlik 'n nuwe soort sorg vir ander, 'n sorg waar religieuse begrippe soos liefde, meelewing en vergifnis nuwe inhoud verkry (Caputo 2004:133 e v). Ek vind Caputo se artikel, by die herlees daarvan in hierdie versamelwerk, nie opnuut as van hoogstaande filosofies-intellektuele gehalte nie, maar ook 'n besonder pastorale en troosvolle teks.

Deel IV, waar Foucault se teologiese epistemologie onder die loep geneem word (getitel Foucault and theological knowledge), open met Thomas Flynn se "Partially desacralized spaces: The religious availability of Foucault's thought", 'n artikel waarin talle filosofiese deeldissiplines mekaar in terme van die groter oeuvre van Foucault ontmoet. Tematies fokus Flynn (2004:145;151) egter op die kategorie van die "gebeure" sowel as die ervaring van die "mistiese" in Foucault se werk. Flynn toon aan dat die grys area tussen die gebeure, die ruimtelike en die ervaring in Foucault se werk, 'n platform verskaf vanwaar 'n dialoog tussen Foucault en die religie op die been gebring kan word. Foucault se volgehoue aksent op die gebeure (as kategorie) vrywaar hom naamlik van 'n ondergeskiktheid aan enige soeke na die metafisiese God van die (ouer) filosowe. Foucault sou hom eerder wou rig, nogmaals, op die teenwoordig-historiese moment, op die vraag na die wyse waarop die onherhaalbare tog wel "herhaal" of herdink kan word, 'n sentiment wat volgens Flynn (2004:150) van 'n diepe eerbied vir die mistiek, trouens 'n "Bybelse sensibiliteit" getuig. Hierdie artikel open nuwe moontlikhede ten opsigte van 'n nuwe eerbied vir die mistiese in die religie, wat juis noodsaaklik is in die lig van wat vandag beleef word as talle teoloë (en kerke) se oppervlakkige pogings om die mistiek te rehabiliteer. Flynn dui aan: Wie die klok van die mistiek hoor lui, moet baie seker maak waar die bel hang. Andersins word die mistiek weldra teatraal, uitgeput, oorspanne en vals. Foucault bevorder 'n diepe eerbied vir die mistiese, allermins eksperimentele proeflopies daarmee.

Tematies sluit Henrique Pinto se "The more that exceeds us: Foucault, Roman Catholicism and inter-faith dialogue" nou by Flynn se bydrae aan. Pinto ontwikkel Foucault se idee van die "meer" in sy The archaeology of knowledge om daarmee die onbegrensde moontlikhede van die verhouding tussen menslikheid en "goddelikheid" te ondersoek. Deur teologie in die gedesentreerde subjek, in historisiteit, in kontingensie en in die begrensde te lokaliseer, poog Pinto om 'n nie-eenheidsteologie van religieuse pluralisme te 
ontwikkel, waarvolgens 'n "etiese aanvoeling vir die Ander", "dialogiese praktyke" en 'n "gekontekstualiseerde openheid vir Ander" getematiseer word. Pinto se artikel is merkwaardig in die sin dat hy hiermee nie bloot 'n teologiese lesing van Foucault aanbied nie, maar 'n teologiese ruimte binne Foucault se werk skep. Hy bring Foucault direk in gesprek met die Rooms-Katolieke Kerk se (meewarige) ekumeniese beleid en herdefinieer mistiek, ook in RoomsKatolieke gedaante, as 'n verskying van die "meer", 'n verskyning wat sigself verset teen die voorskriftelikheid en teologiese afgegrensdheid van die "genoeg", as volgens Pinto 'n sentrale motief in die Rooms-Katolieke tradisie (Pinto 2004:193). Pinto se artikel dien as bevestiging van juis hoe inspirerend Foucault se werk ten opsigte van die teologie kan inwerk, juis omdat dit so inspirerend en oopstellend wil inwerk op die "meer" van mens-wees in die algemeen.

Andrew Cutrofello volg op met 'n belangrike artikel oor die (berugte afwesige) gesprek tussen Foucault en Habermas oor die estetika, om vandaar verder insiggewend Foucault se aansluiting by die Rooms-Katolieke tradisie te omlyn: "Exomologesis and aesthetic reflection: Foucault's response to Habermas". Cutrofello dui aan dat die grondmotief in Foucault se heel laaste werk, die vyf jaar voor sy dood in die besonder, naamlik die "versorging van die Self", deel uitmaak van 'n bewustelike strategie ter ondermyning van die triomfantelike Sokratiese tradisie van "ken jouself". Cutrofello argumenteer dat Foucault gepoog het om die verhouding tussen die liggaam en (artikuleerbare) taal te transevalueer, indien hy dit nie selfs omgekeer het nie. Curtofello (2004:159-160) verken Foucault se interesse in vroeg-Christlike biegpraktyke, veral ten opsigte van die teenstelling van die openbare handeling van die skuldbelydenis van 'n sondaar (oftewel exomologesis) en die verbale belydenis van sondes (oftewel exagoreusis), wat die geformaliseerde Rooms-Katolieke handeling geword het. Foucault se analise van hierdie twee manifestasies van die artikulering van skuld word gevolgryk hervertolk ten aansien van die plek van die sublieme in die teologie.

Juis ten opsigte van die sublieme vind Thomas Beaudoin se bydrae ten opsigte van die musikologiese en díe se verhouding tot 'n teologiese epistemologie, aansluiting: "From singular to plural domains of theological knowledge: Notes toward a Foucaultian new question". Deur te fokus op Foucault se interesse in musiek en die wyse waarop hierdie interesse Foucault se estetika beïnvloed het, poog Beaudoin om die greep van moderne subjektiwiteit op die teologiese domein te ondermyn. Nadat hy breedvoerig aandag gee aan 'n epistemologiese oorweging, te wete "'n meervoud van intelligensies" (Beaudoin 2004:173 e v), heraksentueer en heromlyn Beaudoin die vraag na die wat van die teologie: Wat is teologie? 
Wat doen teologie? Wat moet 'n kennisvorm vermag of nie vermag nie om as teologies gereken te word? Is daar "modusse" van teologiese kennis en is musiek een daarvan? Dit is aangrypend om 'n sogenaamde praktiese teoloog so vaartbelynd met Foucault en die filosofiese estetika in die breë te kan sien werk: Beaudoin stel hiermee ' $n$ belofteryke Foucauldiaanse vraag na die skynbaar noodwendige pluralisme van teologiese oriëntasies en verstaanstyle.

Die laaste deel in die versamelwerk fokus op Foucault se seksualiteitsbeskouing ${ }^{11}$ en in welke mate ' $n$ "liggaamsteologie" vanuit Foucault se befaamde analises van die erotiese liggaam gedistilleer kan word. Redakteur Jeremy Carrette lewer hier 'n besonder waardevolle bydrae tot die Foucault-navorsing ten aansien van die laaste deel van Foucault se gepubliseerde werk, met "Beyond theology and sexuality: Foucault, the Self and the que(e)rying of monotheistic truth". Carrette poog om aan die hand van Foucault se trilogiese seksualiteitsanalise in History of sexuality teologie te heroorweeg buite van wat Foucault beskou het as die regime van seksualiteit, 'n gefikseerde Self en monoteïstiese waarheid (Carrette 2004:223 e v). Carrette argumenteer dat seksualiteit en monoteïstiese teologie fundamenteel verbonde is in die wyse waarop sowel die liggaam as ' $n$ verstaan van God deur beide "beheer" word. Teologiese inspraak in die seksualiteitsdiskoers sit volgens Carrette (2004:227ev) 'n onderdrukkende epistemologie voort, omdat dit die werklikheid steeds in een punt anker. Carrette ondersoek dan die wyse waarop Foucault ons van seksualiteit (as 'n invensie) probeer bevry, om daarmee dieselfde strategie ten opsigte van die teologie se beheer van die liggaam en God aan te lê. In 'n verkenning van Foucault se (tans nog ongepubliseerde) werk oor die Christelike Self, dui Carrette aan in welke mate die Christelike werklikheidsverstaan, in teenstelling met die Boeddhistiese werklikheidsbegrip in die besonder, steeds in die enkelwaarheid van die Self, God en seksualiteit vestig. Uiteindelik roep Carrette die teologie op om beheer oor die liggaam te laat vaar deur in die eerste instansie die bereidwilligheid aan die dag te lê om, as 'n menslike projek met menslike beheermeganismes, beheer oor God te laat vaar.

Carrette skryf besonder boeiend oor sowel die liggaam as oor die implikasies van Foucault se gesprek met die teologie. In hierdie sin plaas hy as redakteur ' $n$ stempel van keurigheid en bedrewenheid op ' $n$ versamelwerk wat in die Foucault-navorsing werklik agting behoort af te dwing.

\footnotetext{
${ }^{11}$ Vir 'n toeganklike bespreking van Foucault se seksualiteitsanalise, kyk Beukes (2002a).
} 


\section{Literatuurverwysings}

Baudrillard, J \& Gane, M (eds) 1993. Baudrillard Live. London: Routledge.

Beardslee, W A, Holland, J \& Griffin, D R 1989. Varieties of postmodern theology. New York: State University of New York.

Beaudoin, T 2004. From singular to plural domains of theological knowledge: Notes toward a Foucaultian new question, in Bernauer, J \& Carrette, J (eds), Michel Foucault and theology: The politics of religious experience, 171-189. Hampshire: Ashgate.

Bernauer, J 1999. Foreword: Cry of the spirit, in Foucault, M, Carrette, J (ed), Religion and culture, xi ff. London: Routledge.

Bernauer, J 2004. Michel Foucault's philosophy of religion: An introduction to the non-fascist life, in Bernauer, J \& Carrette, J (eds), Michel Foucault and theology: The politics of religious experience, 77-97. Hampshire: Ashgate.

Bernauer, J \& Carrette, J (eds) 2004. Michel Foucault and Theology: The politics of religious experience. Hampshire: Ashgate.

Bernstein, R J 1989. Foucault: Critique as philosophic ethos, in Honneth, A et al (Hrsg), Zwischenbetrachtungen, im Prozess der Aufklärung: Jürgen Habermas zum 60 Geburtstag, 395-425. Frankfurt: Suhrkamp.

Beukes, J 1996. Michel Foucault en die historisering van Anderswees. HTS 52, 233251.

Beukes, J 2000. Die redekritiese aansprake van 'n negatief-dialektiese teologie. HTS $56,205-236$.

Beukes, J 2002a. Ars erotica en die detrivialisering van die seksuele diskoers: 'n Aantekening by die seksualiteitsanalise van Michel Foucault. HTS 58, 283298.

Beukes, J 2002b. Vanaf laat-strukturalisme na post-strukturalisme: 'n Kontekstualisering van Jean-François Lyotard se Discours, Figure. HTS 58, 994-1010.

Caputo, J D \& Yont, M 1993. Institutions, normalization, and power, in Caputo, J D \& Yont, M (eds), Foucault and the critique of institutions, 3-26. Pennsylvania, PA: Pennsylvania State University Press.

Caputo, J 2004. On not knowing who we are: Madness, hermeneutics and the night of truth in Foucault, in Bernauer, J \& Carrette, J (eds), Michel Foucault and theology: The politics of religious experience, 117-139. Hampshire: Ashgate.

Carrette, J 1999. Introduction: Approaching Foucault's work on religion, in Foucault and religion: Spiritual corporality and political spirituality, 1-6. London: Routledge.

Carrette, J 2004. Beyond theology and sexuality: Foucault, the self and the que(e)rying of monotheistic truth, in Bernauer, J \& Carrette, J (eds), Michel Foucault and theology: The politics of religious experience, 217-232. Hampshire: Ashgate.

Castelli, E A 2004. Interpretations of power in 1 Corinthians, in Bernauer, J \& Carrette, J (eds), Michel Foucault and theology: The politics of religious experience, 19-38. Hampshire: Ashgate.

Clark, E A 2004. Foucault, the fathers and sex, in Bernauer, J \& Carrette, J (eds), Michel Foucault and theology: The politics of religious experience, 39-56. Hampshire: Ashgate. 
Crockett, C 2001. A theology of the sublime. London: Routledge.

Cutrofello, A 2004. Exomologesis and aesthetic reflection: Foucault's response to Habermas, in Bernauer, J \& Carrette, J (eds), Michel Foucault and theology: The politics of religious experience, 157-169. Hampshire: Ashgate.

Deleuze, G 1984. Nomad thought, in Allison, D B (ed), The new Nietzsche, 141-149. Cambridge: MIT.

Dillon, M 1999. Catholic identity: Balancing reason, faith, and power. Cambridge: Cambridge University Press.

Flynn, T R 2004. Partially desacralized spaces: The religious availability of Foucault's thought, in Bernauer, J \& Carrette, J (eds), Michel Foucault and theology: The politics of religious experience, 143-155. Hampshire: Ashgate.

Foucault, M 1977. Language, counter-memory, practice, tr by D F Bouchard, \& S Simon. Oxford: Blackwell.

Fraser, N (ed) 1989. Foucault on modern power: Empirical insights and normative confusions, in Unruly practices. Minneapolis, MN: University of Minneapolis Press.

Frei, H 1992. Types of Christian theology. New Haven, CN: Yale University Press.

Kelley, S 2002. Racializing Jesus: Race, ideology and the formation of modern biblical scholarship. London: Routledge.

Leezenberg, M 2004. Power and political spirituality: Michel Foucault on the Islamic revolution in Iran, in Bernauer, J \& Carrette, J (eds), Michel Foucault and theology: The politics of religious experience, 99-115. Hampshire: Ashgate.

Niebuhr, H R 1951. Christ and culture. New York: Harper.

Pinto, H 2004. The More that exceeds us: Foucault, Roman Catholicism and interfaith dialogue, in Bernauer, J \& Carrette, J (eds), Michel Foucault and theology: The politics of religious experience, 191-213. Hampshire: Ashgate.

Poxon, J 2000. Embodied anti-theology: The body without organs and the judgement of God, in Bryden, M (ed), Deleuze and religion, 42-50. London: Routledge.

Ray, S A 1988. The modern soul: Michel Foucault and the theological discourse of Gordon Kaufman and David Tracy. New York: Fortress.

Rayment-Pickard, H 2003. Impossible God: Derrida's theology. London: Ashgate.

Rogerson, J W 2000. The potential of the negative: Approaching the Old Testament through the work of Adorno, in Carroll R, M D (ed), Rethinking contexts, rereading texts, 24-47. Sheffield: Sheffield Academic Press.

Schuld, J J 2004. Augustine, Foucault and the politics of imperfection, in Bernauer, J \& Carrette, $\mathrm{J}$ (eds), Michel Foucault and theology: The politics of religious experience, 57-74. Hampshire: Ashgate.

Ten Kate, L 1999. Marges van die teologie. Fragmente 4, 113-130.

Tilley, T W 2000. Postmodern theologies. New York: Orbis.

Viladesau, R 1999. Theological aesthetics: God in imagination, beauty and art. New York: Oxford University Press.

Westphal, M E 2001. Overcoming onto-theology. New York: Fordham University. 